\title{
CEUP
}

CENTRO UNIVERSITÁRIO DE BRASÍLIA - CEUB PROGRAMA DE INICIAÇÃO CIENTÍFICA

GIOVANNA SOUSA DE CASTRO RIBEIRO

ISABELLA DE FREITAS CAVALCANTE

A ASSOCIAÇÃO ENTRE A OBESIDADE E OS POLIMORFISMOS DA INTERLEUCINA-6 E DO RECEPTOR DE LEPTINA 


\title{
CEUP $\backslash$ PIC
}

\author{
GIOVANNA SOUSA DE CASTRO RIBEIRO
}

ISABELLA DE FREITAS CAVALCANTE

\section{A ASSOCIAÇÃO ENTRE A OBESIDADE E OS POLIMORFISMOS DA INTERLEUCINA-6 E DO RECEPTOR DE LEPTINA}

Relatório final de pesquisa de Iniciação Científica apresentado à Assessoria de Pós-Graduação e Pesquisa.

Orientação: Paulo Roberto Martins Queiroz. 


\section{AGRADECIMENTOS}

Primeiramente, gostaríamos de agradecer a todos os profissionais do curso de Biomedicina por todo apoio e dedicação que têm por nós durante o decorrer do curso. Aos alunos e funcionários do CEUB que aceitaram participar deste projeto de pesquisa mesmo com todos os contratempos devido à pandemia. Aos participantes da Assessoria de Pesquisa Científica por todo auxílio e suporte que nos forneceram durante estes semestres e, por fim, ao professor Paulo Queiroz por nos ajudar durante toda esta extensa caminhada que no final foi extremamente gratificante. 


\section{RESUMO}

A obesidade é caracterizada pelo acúmulo intenso de gordura corporal a partir de um desbalanceamento energético, havendo um armazenamento excessivo de energia na forma de triglicerídeos no tecido adiposo. Esta doença tem sido indicada como um quadro inflamatório, pois em indivíduos obesos são produzidos altos níveis de marcadores inflamatórios quando comparados a indivíduos eutróficos, com baixo índice de massa corporal. A obesidade possui uma etiologia multifatorial, relacionando fatores metabólicos, ambientais e genéticos - englobando hereditariedade e polimorfismos. Nesses, ocorrem alterações na sequência de nucleotídeos, proporcionando uma variabilidade que, quando presente nos genes da interleucina- 6 e do receptor da leptina, pode-se associar à obesidade. Diante disso, a presente pesquisa teve como objetivo relacionar os polimorfismos dos genes da interleucina- 6 e do receptor de leptina com a obesidade a partir de uma Pesquisa de Campo construída com artigos publicados nos últimos 20 anos, juntamente com análise dos dados genéticos e do questionário obtidos. Nesta busca, foram utilizados livros de genética, base de dados como SciELO e PubMed, além de teses e dissertações do banco de dados da Universidade de São Paulo e da Universidade de Brasília. A leptina, hormônio secretado pelo tecido adiposo, faz a sinalização hipotalâmica do estoque de gordura, regulando o apetite. Quando está em altos níveis no sangue, tem-se o impedimento da composição de neuropeptídeos associados ao aumento do apetite. Alguns polimorfismos no gene do receptor de leptina, diminuem a especificidade do receptor e a ligação do hormônio à ele. Logo, a sinalização da leptina de inibir a composição de alguns neuropeptídeos diminui, voltando a ter o aumento de apetite, levando ao maior consumo de alimentos e, vinculada ao estilo de vida, pode ocasionar o sobrepeso. Outros polimorfismos associados à obesidade são os do gene da interleucina-6, como o polimorfismo de nucleotídeo único -174C/G, que eleva a produção deste mediador inflamatório e, subsequentemente, à concentração sérica, ampliando a resposta inflamatória aguda e reforçando que o sobrepeso deve ser classificado como uma inflamação. Associada à obesidade, normalmente, tem-se Diabetes Mellitus tipo 2, Doenças Cardiovasculares e Síndrome Metabólica, tendo essas em comum, uma maior concentração sérica de interleucina-6. Logo, verifica-se que a obesidade está intimamente ligada aos polimorfismos do gene da interleucina- 6 e do receptor de leptina, bem como aos respectivos fatores de risco, sendo fundamental a análise dessa associação. Tal informação foi averiguada na pesquisa, de forma que houve uma diferença significativa da presença do polimorfismo em pacientes obesos em relação aos voluntários não obesos. Também foi vista uma conexão entre o meio-ambiente e a expressão ou não da obesidade, reforçando que mecanismos epigenéticos devem ser elucidados para a intervenção e o tratamento desse quadro inflamatório.

Palavras-chave: epigenética; quadro inflamatório; SNPs; sobrepeso. 


\section{LISTA DE FIGURAS}

Figura 1 - Localização do gene da leptina no cromossomo 7 e do LEPR no cromossomo 1, indicados pela linha vermelha.

Figura 2 - Representação esquemática do gene do receptor de leptina e dos seus principais polimorfismos.

Figura 3 - Localização do gene da interleucina-6 no cromossomo 7, indicado pela linha vermelha.

Figura 4 - Esquema representativo da resposta imunológica associada aos marcadores inflamatórios que podem desencadear a DM2.

Figura 5 - Gel representativo de PCR-RFLP do produto do gene da IL-6 (174-G/C).

Figura 6 - Gel representativo de PCR-RFLP do produto do gene do LEPR (668A>G). 


\section{LISTA DE QUADROS}

Quadro 1 - Resultados estatísticos dos pacientes organizados em grupos e de acordo com os valores $\mathrm{p}$ e de Shapiro-Wilk.

Quadro 2 - Síntese dos dados apresentados no questionário a respeito dos pacientes com IMC menor que $25 \mathrm{~kg} / \mathrm{m}^{2}$. 


\section{LISTA DE GRÁFICOS}

Gráfico 1 - Análise dos genótipos do gene da IL-6 apresentados pelos voluntários da pesquisa.

Gráfico 2 - Análise dos genótipos do gene do LEPR apresentados pelos voluntários da pesquisa.

Gráfico 3 - Sinalização de pacientes com a distribuição genotípica para os genes da IL-6 e do LEPR, respectivamente, analisados.

Gráfico 4 - Separação dos grupos de indivíduos analisados na pesquisa de acordo com o Índice de Massa Corporal. 


\section{LISTA DE ABREVIAÇÕES}

a-MSH

A

AVE

C

CEP

CCK

$\mathrm{CRH}$

DCV

DM2

DNA

dNTP

FACES

G

GLUT-4

HAS

IL-6

IL-6R

IMC

LEP

LEPR

Mspl

NCBI

NPY

OMS

SIL-6R

SM

SNP

$\mathrm{pb}$

PCR

PCR
Hormônio estimulante de alfa-melanócito

Adenina

Acidente Vascular Encefálico

Citosina

Comitê de Ética e Pesquisa

Hormônio colecistocinina

Liberador de corticotropina

Doenças Cardiovasculares

Diabetes Mellitus 2

Ácido desoxirribonucleico

Desoxirribonucleotídeos Fosfatados

Faculdade de Ciências e Saúde

Guanina

Transportador de glicose

Hipertensão Arterial Sistêmica

Interleucina-6

Receptor de interleucina-6

Índice de Massa Corporal

Leptina

Receptor de leptina

Enzima de restrição Moraxella sp.

National Center of Biotechnology Information

Neuropeptídeo Y

Organização Mundial da Saúde

Receptor de interleucina-6 solúvel

Síndrome Metabólica

Polimorfismo de Nucleotídeo Único

Pares de bases

Proteína C Reativa

Reação em Cadeia de Polimerase 
PCR-RFLP

Análise de Polimorfismo de comprimento de fragmentos de restrição utilizando a Reação em Cadeia de Polimerase

$\mathrm{T}$ Timina

TNF- $\alpha$

Fator de necrose tumoral alfa

TCLE

Termo de Consentimento Livre e Esclarecido 
SUMÁRIO

1. INTRODUÇÃO

2. FUNDAMENTAÇÃO TEÓRICA 2

3. MÉTODO 8

4. RESULTADOS E DISCUSSÃO 12

5. CONSIDERAÇÕES FINAIS 20

REFERÊNCIAS 21

APÊNDICES 25 


\section{INTRODUÇÃO}

A obesidade é uma doença classificada pelo acúmulo intenso de gordura corporal a partir de uma alteração do balanço energético, no qual ocorre um armazenamento excessivo de energia sob a forma de triglicerídeos no tecido adiposo. Este processo desencadeia alterações maléficas para a saúde do indivíduo, tais como, comprometimentos respiratórios, dificuldades no aparelho locomotor e, até mesmo, patologias como Diabetes Mellitus tipo 2 (DM2), doenças cardiovasculares (DCV), Síndrome Metabólica (SM) e câncer. Devido ao crescimento de casos, atualmente, a obesidade é vista como uma desordem nutricional de extrema relevância para a saúde pública, sendo fundamental a ampliação de estudos sobre esta alteração (WANDERLEY; FERREIRA, 2007; OLIVEIRA, 2011).

Alguns definem essa doença como um quadro inflamatório, pois em pessoas obesas são produzidos, por macrófagos presentes no tecido adiposo branco, altos níveis de marcadores inflamatórios, como a proteína $C$ reativa $(P C R)$, o fator de necrose tumoral alfa (TNF- $\alpha$ ), a interleucina-6 (IL-6) e as quimiocinas, quando comparados com indivíduos eutróficos e de baixo índice de massa corporal. Recentemente, estudos também têm mostrado que a obesidade vincula-se a infiltração leucocitária, que ocorre durante o processo de inflamação, reforçando a ideia de ser um distúrbio inflamatório (GHOSH; ASHCRAFT, 2013; FUNGHETTO, 2014).

A sua etiologia é complexa e multifatorial, podendo envolver a interrelação entre fatores genéticos, emocionais, metabólicos e ambientais. Estes últimos abrangem influências culturais, histórico-ecológicas, socioeconômicas, psicossociais e do estilo de vida, referente ao aporte energético da dieta e à intensidade da prática de atividade física, o que tem sido amplamente discutido na contemporaneidade (WANDERLEY; FERREIRA, 2007; ABESO, 2016).

Já em relação aos fatores genéticos, há a questão hereditária - na qual são descritas 24 doenças mendelianas que desencadeiam a obesidade precoce na infância como, por exemplo, a Síndrome de Prader-Willi, além das doenças monogênicas não mendelianas - e os polimorfismos em genes, nos quais tem-se escassas pesquisas e análises. Nestes polimorfismos, são vistas alterações na sequência de bases nitrogenadas, proporcionando uma variabilidade que gera diferentes expressões - das que seriam consideradas adequadas em uma mesma sequência de nucleotídeos codificante de transcritos. Logo, acredita-se que 
as alterações nos genes da IL-6 e do LEPR estão ligadas à patologia da obesidade (STEEMBURGO; AZEVEDO; MARTÍNEZ, 2009; OLIVEIRA, 2011; ABESO, 2016).

Diante das informações supracitadas, esta pesquisa teve como objetivo analisar os polimorfismos de genes envolvidos na homeostase energética, sendo eles o gene codificador do receptor da leptina (LEPR) e o gene da interleucina-6 (IL-6), e suas relações com a obesidade, para gerar futuros esclarecimentos científicos, como a compreensão dos aspectos que podem levar a classificação da doença como inflamatória, e contribuir com novas formas de tratamento para essa patologia. Ademais, buscou-se entender a correlação entre os fatores externos e a indução da capacidade polimórfica do gene, a partir de aplicações de questionários e análise do DNA.

\section{FUNDAMENTAÇÃO TEÓRICA}

O DNA dos seres humanos é composto por uma sequência de bases nitrogenadas que alternam entre si e a partir dessa cadeia é possível se obter os genes, responsáveis pelas características de um determinado indivíduo. Devido a capacidade de formação de inúmeras sequências diferentes de nucleotídeos é criada a variabilidade genética da população. Porém, em determinados locais do cromossomo, também denominados de loci, essa ordem específica na sequência do DNA pode sofrer alterações classificadas como polimorfismos (NUSSBAUM et al., 2008).

Categoriza-se uma variante como um polimorfismo quando a sua frequência alélica é superior a $1 \%$ dos alelos populacionais, não devendo levar em consideração, para essa segregação, a mutação que o causou, o tamanho do segmento genômico envolvido, o efeito que ele estabelece no indivíduo ou a sua localização no gene. A frequência dessas modificações pode alterar de acordo com a população estudada, contudo, é possível observar que a maior parte dos alelos variantes não chegam ao nível de frequência suficiente, no grupo populacional, para ser considerado um polimorfismo, classificando-os como alelos "particulares" (ROCHA et al., 2007; NUSSBAUM et al., 2008).

Ademais, como os polimorfismos são transmitidos em associação a outros genes que estejam adjuntos a região cromossômica afetada (linkage), é possível compreender que os polimorfismos podem operar como marcadores genéticos. Portanto, caso haja um gene 
perto do marcador de uma determinada doença, todos os familiares acometidos irão receber o gene que desencadeará a patologia e o marcador (ROCHA et al., 2007).

A maioria dos polimorfismos são localizados entre genes ou inclusos aos íntrons e, normalmente, são insignificantes para o funcionamento genômico. Outros polimorfismos podem estar situados na região codificadora do próprio gene, resultando em proteínas modificadas, como as truncadas, e que possibilitariam gerar alterações distintas na sociedade. Há também polimorfismos que ocorrem em regiões reguladoras, havendo consequências na transcrição e na estabilidade do RNA. Em virtude dessas decorrências, os polimorfismos são imprescindíveis para a análise da genética humana e médica, fornecendo um leque de possibilidades para estudos e pesquisas (NUSSBAUM et al., 2008).

Significativas associações de polimorfismos com o consumo de nutrientes e a gordura, em especial, são evidenciadas por pesquisas, enfatizando a importância da nutrigenética. A ingestão de gordura é um elemento primordial nos fenótipos da obesidade, servindo como um ativador de polimorfismos em determinados genes como, por exemplo, o que codifica a IL-6 e o receptor da leptina (LEPR) (STEEMBURGO; AZEVEDO; MARTÍNEZ, 2009).

$\mathrm{Na}$ obesidade tem-se um demasiado acúmulo da quantidade de gordura no tecido adiposo, o que pode desencadear diversas alterações na saúde da pessoa, sendo um fator de risco para doenças cardiovasculares e para a DM2, como dito anteriormente. Esse excesso de sobrepeso advém da complexa interação entre fatores genético-metabólicos e estilo de vida, sendo diagnosticado através de um quociente, estabelecido pela Organização Mundial da Saúde (OMS), entre o peso corporal e a estatura do indivíduo, resultando no Índice de Massa Corporal (IMC) (WANDERLEY; FERREIRA, 2007; OLIVEIRA, 2011).

Algumas substâncias envolvidas no controle da ingestão alimentar que associam-se à obesidade são os hormônios colecistocinina (CCK) e grelina, o neuropeptídeo Y (NPY) e o peptídeo YY. A CCK e o peptídeo YY são liberados pelo trato gastrointestinal e ao nível cerebral inibem a fome, promovendo a saciedade após uma refeição. Já a grelina estimula a ingestão, bem como o NPY, que é produzido no hipotálamo quando os níveis de insulina e leptina estão diminuídos (WANDERLEY; FERREIRA, 2007).

A leptina, um outro hormônio que interfere na obesidade, é secretado pelo tecido adiposo devido a uma resposta à excedente de gordura ingerida ou à retenção desta no organismo. Essa substância química liberada na corrente sanguínea, faz a sinalização 
hipotalâmica do estoque de gordura, além de intervir no gasto energético, na sensibilização insulínica e na regulação do apetite, mantendo assim, o controle homeostático (WANDERLEY; FERREIRA, 2007; OLIVEIRA, 2008; OLIVEIRA, 2011).

A redução do apetite ocorre porque através da leptina há o impedimento da composição de neuropeptídeos oxígenos, que estão associados ao aumento da apetência, e uma maior expressão de neuropeptídeos anorexígenos, nos quais têm-se o hormônio estimulante de alfa-melanócito ( $\alpha-\mathrm{MSH})$ e o liberador de corticotropina ( $\mathrm{CRH}$ ) que diminuem a ingestão alimentar e estimulam a hipófise. Logo, é possível observar que a deficiência do CRH é responsável de 1 a $2 \%$ dos casos de obesidade mórbida precoce (WANDERLEY; FERREIRA, 2007; OLIVEIRA, 2008).

Como observado na figura 1 , a codificação desta leptina é dada a partir do gene LEP localizado no cromossomo 7 (7q31.3), possuindo $18 \mathrm{~kb}$ de extensão e 3 éxons que transcrevem um RNAm de 3,5 kb. Enquanto o gene do seu receptor (LEPR), também denominado OB-R, tem tamanho de $70 \mathrm{~kb}$, localiza-se no cromossomo 1 (1p31) e contém 20 éxons, podendo ser codificado de diferentes isoformas através do splicing (OLIVEIRA, 2008; OLIVEIRA, 2011).

Figura 1: Localização do gene da leptina no cromossomo 7 e do LEPR no cromossomo 1, indicados pela linha vermelha.

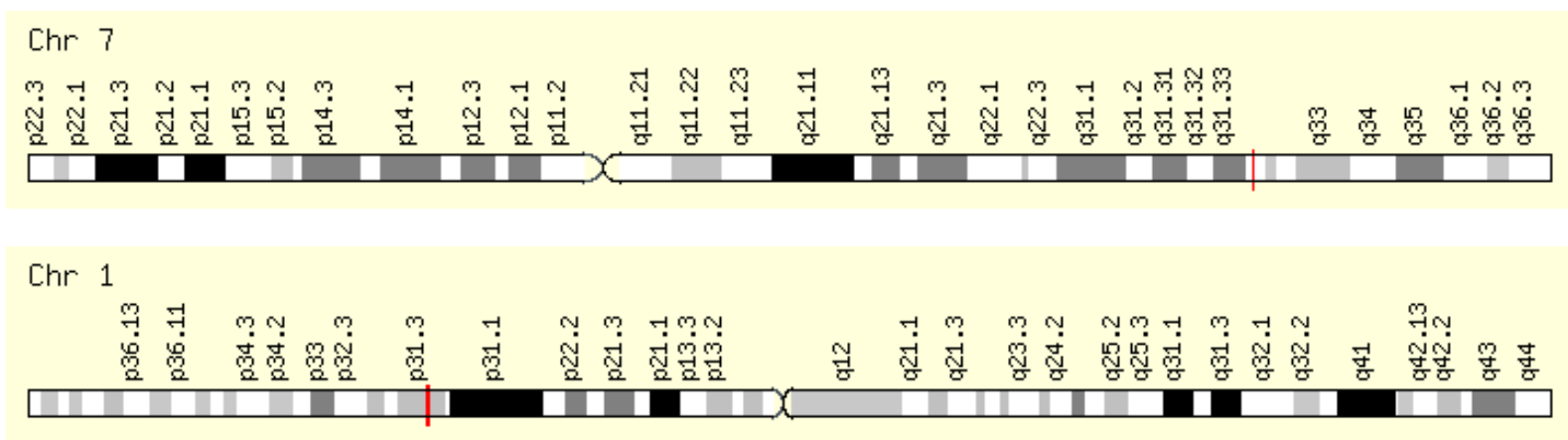

Fonte: Adaptado de GENECARDS (2021b); GENECARDS (2021c).

Polimorfismos localizados nesses genes têm sido associados aos fenótipos da obesidade em diversas populações e duas alterações comuns do LEPR são a Lys109Arg (c.326A>G), Lys656Asn e Gln223Arg (c.668A>G), conforme apresentadas na figura 2, que possivelmente diminuem a especificidade do receptor e, consequentemente, a ligação do 
hormônio a ele. Logo, a ação da leptina de inibir a composição de neuropeptídeos oxígenos diminui, voltando a aumentar o apetite na pessoa. A alta dessa apetência leva ao maior consumo de alimentos e, vinculada ao estilo de vida, pode causar um desequilíbrio da homeostase energética e uma subsequente obesidade (OLIVEIRA, 2011).

Figura 2: Representação esquemática do gene do receptor de leptina e dos seus principais polimorfismos.

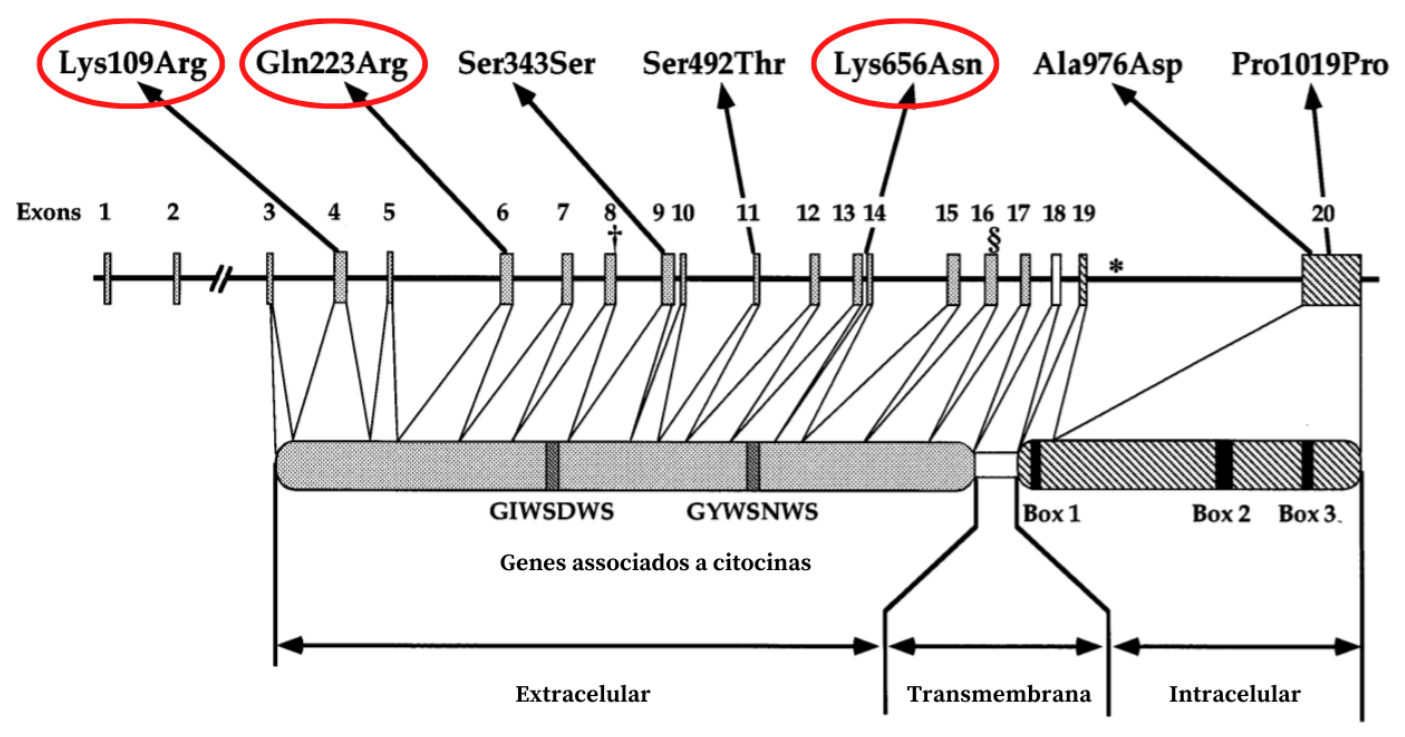

Fonte: Adaptado de MATSUOKA (1997).

Outros polimorfismos de nucleotídeos únicos (SNP) associados à obesidade são os que ocorrem no gene da IL-6, como apresentado na figura 3, podendo elevar a produção deste mediador inflamatório (liberado por granulócitos, principalmente os macrófagos) e, consequentemente, a sua concentração sérica. Logo, a IL-6 é classificada como uma citocina pró-inflamatória e uma miocina anti-inflamatória, sendo produzida, transitoriamente, frente a respostas imunológicas, hematopoiese e reações inflamatórias (TONET; NÓBREGA, 2008; GHOSH; ASHCRAFT, 2013; SOBHAN et al., 2020).

O gene da IL-6 localiza-se no cromossomo 7 (7p21-24), possuindo um promotor a montante que contém 303 pares de base, composto por 5 éxons e um comprimento de $5 \mathrm{~kb}$. Este gene, fundamental mediador da fase aguda, é responsável por codificar uma citocina imunomoduladora com ações pró ou anti-inflamatórias, a interleucina-6, que é secretada no 
hipotálamo e que desempenha uma atividade no gasto energético e na regulação do apetite (OLIVEIRA 2011; ALI et al., 2020; SOBHAN et al., 2020).

Figura 3: Localização do gene da interleucina-6 no cromossomo 7 , indicado pela linha vermelha.

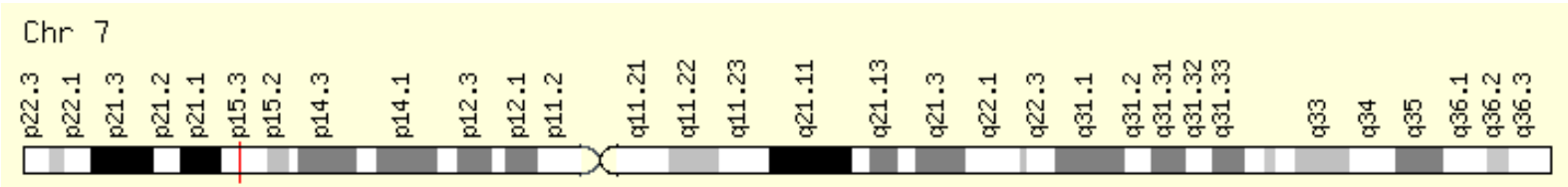

Fonte: GENECARDS (2021a).

No gene desta interleucina, existem SNP nas posições -174C/G, com maior relevância em pesquisas, -597G/A e -572G/C. Acredita-se que a mudança de guanina (G) para citosina (C) na posição -174 altera os níveis plasmáticos da IL-6, pois afeta a transcrição genômica, ampliando a resposta inflamatória aguda. Esta ideia reforça a teoria de que o sobrepeso excessivo deve ser classificado como um quadro de inflamação (GOYENECHEA; PARRA; HERNÁNDEZ, 2005; TONET; NÓBREGA, 2008; STEEMBURGO; AZEVEDO; MARTÍNEZ, 2009; GHOSH; ASHCRAFT, 2013; FUNGHETTO, 2014).

Além de ser um mediador inflamatório, assim como a TNF alfa, a IL-6 influencia na metabolização de lipídeos e de glicose a partir da inibição da lipoproteína lipase, que acaba induzindo a lipólise e o aumento da captação do monossacarídeo. A partir disso, é possível observar que essa citocina apresenta níveis séricos e do tecido adiposo aumentados no sobrepeso excessivo (STEEMBURGO; AZEVEDO; MARTÍNEZ, 2009; GHOSH; ASHCRAFT, 2013).

Associada à obesidade, normalmente tem-se problemas fisiopatológicos como a Diabetes Mellitus tipo 2 (DM2), as Doenças Cardiovasculares (DCV) e a Síndrome Metabólica (SM). Essas quatro doenças têm como ponto de interseção a maior concentração sérica de IL-6 (TONET; NÓBREGA, 2008).

Como demonstrado na figura 4, no momento da resposta imunológica, os macrófagos presentes no tecido adiposo branco produzem níveis elevados de marcadores inflamatórios de resposta aguda (como a PCR, a TNF- $\alpha$ e a IL-6) e, com o polimorfismo -174C/G, que gera o subsequente aumento sérico de IL-6, há o estresse crônico do sistema imune, o que acarreta no declínio da sensibilidade de insulina, levando ao desenvolvimento da DM2. Desta forma, a existência de SNPs no promotor da IL-6 pode ser visto como um fator de risco para a 
Diabetes Mellitus tipo 2, já que a disposição dos genótipos daquela citocina é discrepante em indivíduos não-diabéticos e diabéticos, pois a sequência GC é predominante nos portadores dessa patologia (GOYENECHEA; PARRA; HERNÁNDEZ, 2005; TONET; NÓBREGA, 2008).

Figura 4: Esquema representativo da resposta imunológica associada aos marcadores inflamatórios que podem desencadear a DM2.

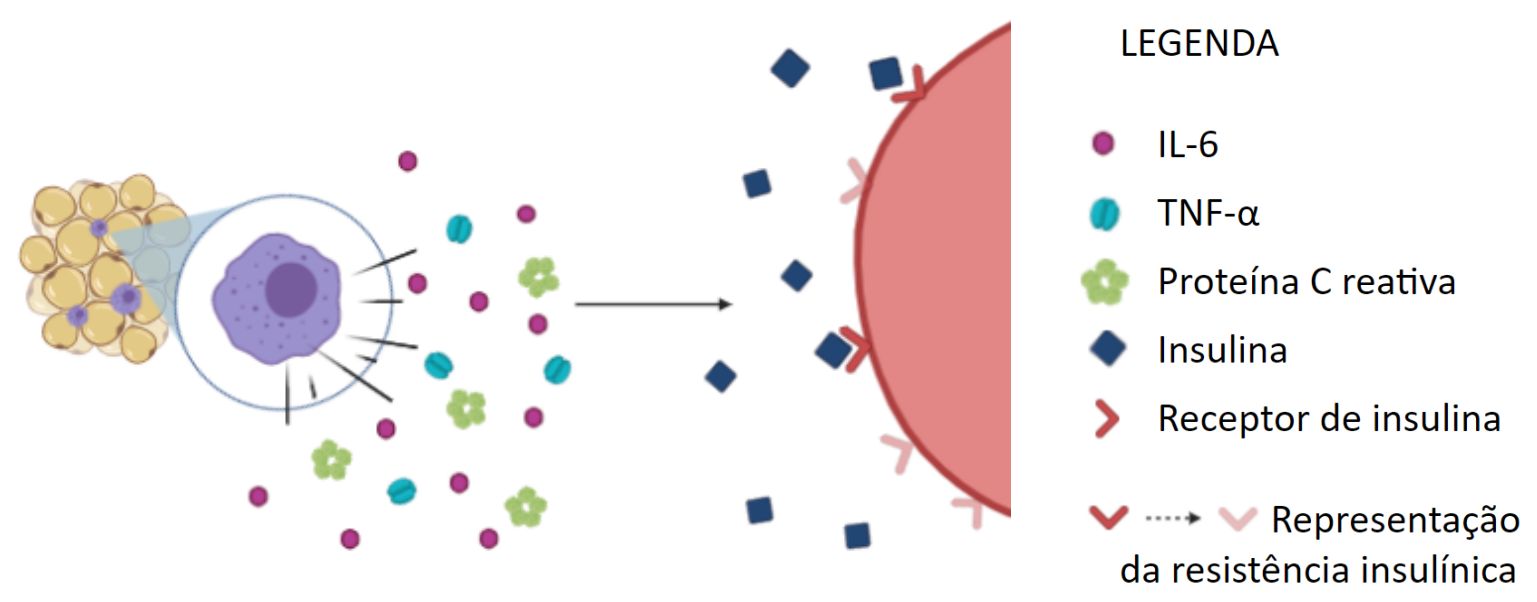

Fonte: Próprio autor.

Em relação ao fator de necrose tumoral alfa, a sua produção excessiva induz a redução, por todo o corpo, da síntese de receptores de insulina, contribuindo para a resistência insulínica presente na DM2 e na obesidade (TONET; NÓBREGA, 2008).

Já a PCR, que é uma relevante proteína da fase aguda com ações pró ou anti-inflamatórias, tem sua síntese induzida sobretudo pela IL-6, refletindo em um aumento da inflamação e progressão maior da patologia. Essa proteína $C$ reativa, em conjunto com a IL-6, pode relacionar-se com aterosclerose, aumento da pressão sanguínea e infarto do miocárdio e o uso combinado dos níveis plasmáticos de ambas gera um prognóstico mais preciso em casos de Acidente Vascular Encefálico (AVE) do que quando são mensuradas dissociadamente (TONET; NÓBREGA, 2008; CARVALHO et al, 2016).

Ademais, há a existência do polimorfismo 48867A>C (Asp358Ala) no gene codificador do receptor da IL-6 (IL-6R), no qual leva a substituição de aspartato por alanina, e, pressupõe-se, que isso eleva a concentração da forma solúvel do receptor da IL-6 (sIL6-R) em pacientes com SM. Com a maior presença de sIL-6, mais moléculas de IL-6 se unem à ele, 
inicializando um complexo que potencializa os efeitos desta citocina, possibilita a ativação de células que não expressam o IL-6R e prolonga a duração da interleucina-6 a nível plasmático (PIRES, 2009; VARGAS, 2012).

Este complexo sIL-6R/IL-6 relaciona-se com a resistência insulínica e com a redução da expressão do transportador de glicose (GLUT-4) nos tecidos muscular e hepático. Logo, é vista uma maior concentração de sIL-6R em pessoas com mais Asp, sendo um alerta para a Síndrome Metabólica e predisposição de maior estado inflamatório, conectando-se à obesidade (PIRES, 2009; VARGAS, 2012).

Feitas essas considerações, é verificado que esta patologia, de excesso de sobrepeso, está intimamente ligada aos polimorfismos do gene da IL-6 e da LEPR, bem como seus respectivos os fatores de risco (TONET; NÓBREGA, 2008).

\section{MÉTODO}

\subsection{Aprovação ética}

Inicialmente, o projeto foi submetido ao Comitê de Ética em Pesquisa (CEP) do Centro Universitário de Brasília - CEUB. Após a aprovação pelo CEP, o mesmo foi aplicado mantendo-se a integridade, a individualidade, a confidencialidade, o sigilo e a inviolabilidade dos dados obtidos a partir dos participantes da pesquisa. O projeto foi aprovado em 04 de dezembro de 2019, recebendo o CAAE: 24361219.5.0000.0023, sob o parecer número 3.744.825.

Os dados obtidos dos participantes da pesquisa seguiram as orientações que estão preconizadas na Resolução no 466/12, do Conselho Nacional de Saúde (CNS) que aprova as diretrizes e normas regulamentadoras de pesquisas envolvendo seres humanos, a Constituição Federal de 1988, o Pacto Internacional sobre os Direitos Civis e Econômicos, a Convenção Americana sobre os Direitos Humanos, e mais recentemente a Lei n. 13.709, de 14 de agosto de 2018, que dispõe sobre a proteção de dados pessoais e a Lei n. 13.787, de 17 de dezembro de 2018, que trata da digitalização e da utilização de sistemas informatizados para a guarda, armazenamento e manuseio de prontuário de paciente, além de outras normas do ordenamento jurídico brasileiro. 
A manipulação do material genético dos participantes da pesquisa seguiu o disposto na Resolução № 340, de 8 de julho de 2004 que trata das Diretrizes para Análise Ética e Tramitação dos Projetos de Pesquisa da Área Temática Especial de Genética Humana, seguindo-se a legislação que vigora e ordena a manutenção de material genético humano em biorrepositório, reservatórios cujos materiais biológicos coletados ficam armazenados ao longo da pesquisa específica, sob responsabilidade institucional e sob gerenciamento do pesquisador, sem haver fins comerciais.

\subsection{Recrutamento e coleta de dados do participante}

Inicialmente foram selecionados 46 participantes da pesquisa maiores de 18 anos pertencentes à comunidade acadêmica do CEUB, recrutados mediante convite de forma presencial.

Como critério de inclusão foram selecionados participantes da pesquisa que se apresentaram de forma voluntária para participar do estudo. Com relação ao critério de exclusão, foram rejeitadas pessoas que estivessem realizando dieta medicamentosa devido a distúrbios metabólicos.

\subsection{Consentimento livre e esclarecido}

Os pesquisadores forneceram o Termo de Consentimento Livre e Esclarecido (TCLE) antes do início do estudo. Ao concordarem com o termo, os participantes preencheram um Questionário para a coleta de dados, que foi disponibilizado em um formulário através do Google Forms. Em sequência, o material genético dos participantes foi fornecido por meio da coleta de $15 \mathrm{ml}$ de bochecho da mucosa bucal.

No questionário foram realizadas perguntas a respeito da qualidade de vida, incluindo os hábitos alimentares e as práticas de exercícios físicos, e a análise de predisposições genéticas interligadas a determinadas doenças. Também foram realizadas a pesagem e a medição da altura dos participantes da pesquisa para a realização da determinação do Índice de Massa Corporal (IMC) visando estabelecer critérios para o grau de obesidade, feito a partir do preceito estipulado pela Organização Mundial da Saúde (OMS).

Foram classificados como indivíduos obesos os participantes que obtiveram um valor 
de IMC igual ou superior a $30 \mathrm{~kg} / \mathrm{m}^{2}$; com sobrepeso entre 25 e $29,9 \mathrm{~kg} / \mathrm{m}^{2}$; eutróficos de 18,5 a $24,9 \mathrm{~kg} / \mathrm{m}^{2}$; e abaixo do peso (magreza) quando $<18,5 \mathrm{~kg} / \mathrm{m}^{2}$.

\subsection{Extração de DNA da mucosa da boca}

A coleta de material e respectiva extração de DNA genômico foram realizadas nas instalações do Labocien, instituição pertencente ao CEUB. O DNA foi obtido a partir de células da mucosa bucal. Os participantes da pesquisa realizaram um bochecho de 30 segundos com $15 \mathrm{~mL}$ de água glicosada. Em seguida, foi realizada uma raspagem da mucosa bucal com uma espátula descartável, que foi homogeneizada nos $15 \mathrm{~mL}$ do bochecho previamente obtido.

Depois, $5 \mathrm{~mL}$ do conteúdo do bochecho foram transferidos, por meio de uma micropipeta automática, para um tubo de ensaio, no qual adicionou-se cloreto de sódio o suficiente para que a parte inferior côncava do tubo fosse totalmente preenchida e, com movimentos cuidadosos, a solução foi agitada até a completa dissolução do sal. Em seguida, adicionou-se $500 \mu \mathrm{L}$ de detergente diluído (1:4) e o tubo foi levado ao banho-maria regulado para uma temperatura de $55^{\circ} \mathrm{C}$ durante 10 minutos.

Posteriormente, o tubo de ensaio contendo a solução foi resfriado por 5 minutos em um recipiente contendo água. Finalmente, foi adicionado lentamente ao tubo uma quantidade equivalente de 1 volume $(6 \mathrm{~mL})$ de álcool gelado para a formação de uma solução bifásica aquosa/etanólica. O precipitado de DNA foi coletado na fração alcoólica com pipeta Pasteur de plástico e depositado em um microtubo de 1,5 mL.

O DNA foi purificado por centrifugação a 12.000xg por 5 min. O sobrenadante foi dispensado e foram adicionados $500 \mu \mathrm{L}$ de álcool $70 \%$. O tubo foi centrifugado por 5 minutos a $12.000 x g$. Esse sobrenadante foi descartado e o procedimento de lavagem com álcool 70\% repetido. Ao final, o DNA foi seco e ressuspenso com $100 \mu \mathrm{L}$ de tampão TE $0,1 \mathrm{X}$.

\subsection{Análise dos polimorfismos genéticos}

O polimorfismo do IL-6 -174G >C ( $\mathrm{s} 1800795)$ foi genotipado usando a técnica de reação em cadeia de polimerase de polimorfismos de comprimento de fragmentos de restrição (PCR-RFLP), para isso foram usados os iniciadores 5'-TGACTTCAGCTTTACTCTTTGT-3' e reverso 5'-CTGATTGGAAACCTTATTAA-3'. 
Na reação de PCR foram utilizadas as seguintes concentrações de reagentes, tampão de PCR 1X, 0,2 uM de cada iniciador, 0,2 mM de dNTP's, $1 U$ Taq DNA polimerase, $50 \mathrm{ng}$ de DNA e água livre de nuclease para 20 ul.

A região polimórfica foi amplificada por PCR com desnaturação inicial de $95{ }^{\circ} \mathrm{C}$ por 3 min, sendo estabelecidos 35 ciclos para desnaturação a $95^{\circ} \mathrm{C}$ por 30s, anelamento a $62{ }^{\circ} \mathrm{C}$ por $90 \mathrm{~s}$ e extensão a $72{ }^{\circ} \mathrm{C}$ por $45 \mathrm{~s}$. Ao final dos ciclos foi feita uma extensão final a $72{ }^{\circ} \mathrm{C}$ por $5 \mathrm{~min}$.

Os produtos da PCR foram digeridos com enzima de restrição Streptococcus faecalis ND547 (SfaNI) a $37{ }^{\circ} \mathrm{C}$ por $16 \mathrm{~h}$, e depois, os fragmentos foram analisados por eletroforese em gel de agarose corado a 2,0\% com brometo de etídio. O produto digerido de PCR-RFLP gerou os seguintes fragmentos: homozigoto tipo selvagem (GG), 140 pb e 58 pb; genótipo heterozigoto (GC), 198 pb, 140 pb e 58 pb; e genótipo mutante homozigoto (CC), de 198 pb.

Já o polimorfismo do LEPR 668A>G (rs1137101) foi genotipado usando a técnica de reação em cadeia de polimerase de polimorfismos de comprimento de fragmentos de restrição (PCR-RFLP). Para a realização deste procedimento, foram usados os iniciadores 5'-ATGTTGTGAATGTCTTGTGCCGG-3' e reverso 5'-CCATATTTATGGGCTGAACTGACATTAG-3'.

Na reação de PCR foram utilizadas as seguintes concentrações de reagentes, tampão de PCR 1X, 0,2 uM de cada iniciador, 0,2 mM de dNTP's, 1 U Taq DNA polimerase, $50 \mathrm{ng}$ de DNA e água livre de nuclease para 20 ul.

A região polimórfica foi amplificada por PCR com desnaturação inicial de 95 ㄷ por 5 min, sendo estabelecidos 35 ciclos para desnaturação a 95 ㄷ C por 30s, anelamento a 62 ㄷ C por $90 \mathrm{~s}$ e extensão a 72 o C por $45 \mathrm{~s}$. Ao final dos ciclos foi feita uma extensão final a 72 ㅇ C por $5 \mathrm{~min}$.

Os produtos da PCR foram digeridos com enzima de restrição Moraxella sp. (Mspl) a $37{ }^{\circ} \mathrm{C}$ por $16 \mathrm{~h}$, e depois, os fragmentos foram analisados por eletroforese em gel de agarose corado a 2,0\% com brometo de etídio. O produto digerido de PCR-RFLP gerou os seguintes fragmentos: homozigoto (GG), 243 pb e 123 pb; genótipo heterozigoto ( $A G), 366$ pb, 243 pb e 123 pb; e genótipo mutante homozigoto (AA), de 366 pb.

A partir da análise dos genótipos dos participantes foram realizadas verificações para se determinar a existência de correlações entre os polimorfismos e os fatores ambientais e genéticos. 


\section{RESULTADOS E DISCUSSÃO}

Ao realizar o processamento das amostras após a técnica de PCR, foi possível observar como o gel de PCR-RFLP do gene da IL-6 foi obtido. A figura 5 mostra a distribuição das bandas de DNA, de forma representativa, na qual há o indicador de massa molecular 100 pb Ladder no gel, representado pela letra M; o perfil do genótipo GC com os fragmentos de 198, 140 e 58 pb indicado pelo número 1; o genótipo GG (140 e 58 pb) apontado pelos números 2 e 4; e, por fim o genótipo CC com fragmento 198 pb apontado pelo número 3.

Figura 5: Gel representativo de PCR-RFLP do produto do gene da IL-6 (174-G/C).

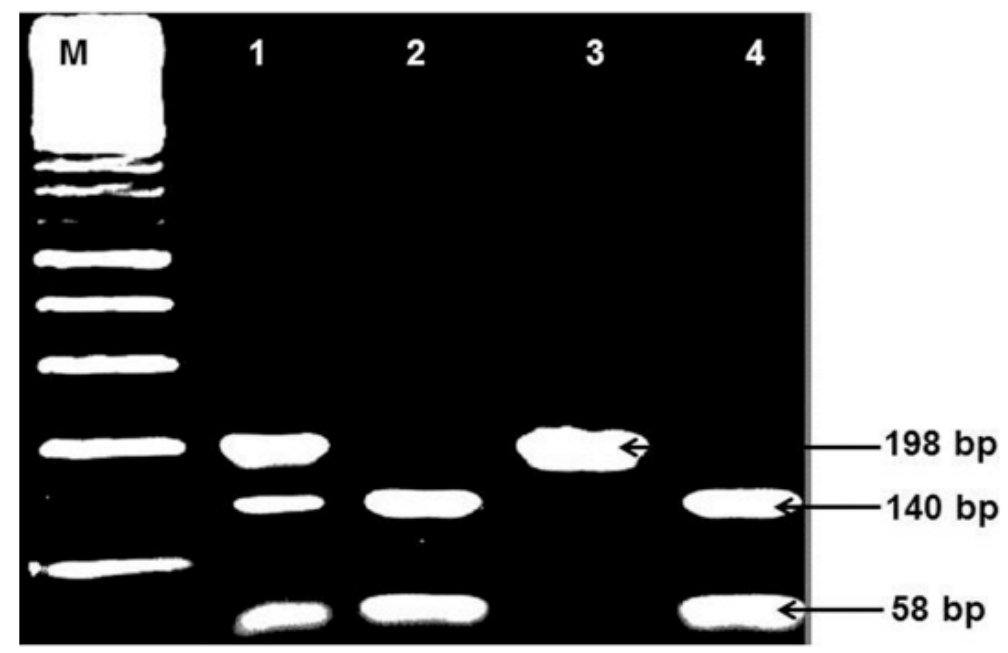

Fonte: AL OKAILY et al. (2020).

Os dados obtidos na eletroforese foram analisados e verificou-se na presente pesquisa, abrangendo todos os participantes, que os genótipos GG, GC e CC, do polimorfismo do gene IL-6, foram identificados nas respectivas porcentagens aproximadas, de acordo com do gráfico 1: 43,5\%; 45,7\% e 10,9\%. Dessa forma, apenas 10,9\% dos participantes apresentaram o genótipo mutado em análise (CC). 
Gráfico 1: Análise dos genótipos do gene da IL-6 apresentados pelos voluntários da pesquisa.

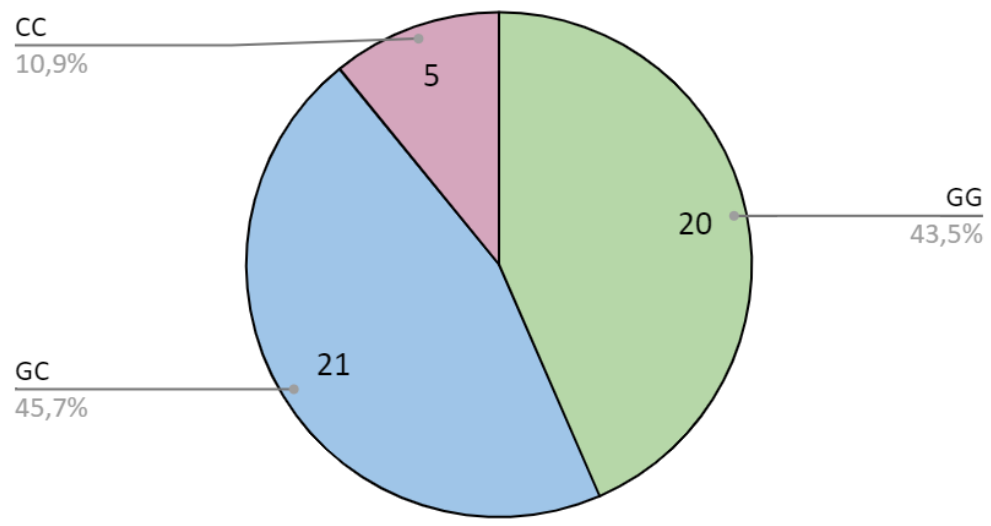

Fonte: Próprio autor.

Já o gel que representa a técnica de PCR-RFLP do gene do LEPR, como observado na figura 6, foi subdividido em 9 colunas. 0 número 9 indica o marcador de massa molecular 100 pb Ladder; os números 1, 2, 4, 5 e 6 correspondem ao genótipo GG com os fragmentos de 243 e 123 pb; os números 3 e 7 indicam o genótipo AA (366pb); e por último o número 8 determina o genótipo AG com os fragmentos de 366, 243 e 123 pb.

Figura 6: Gel representativo de PCR-RFLP do produto do gene do LEPR (668A>G).

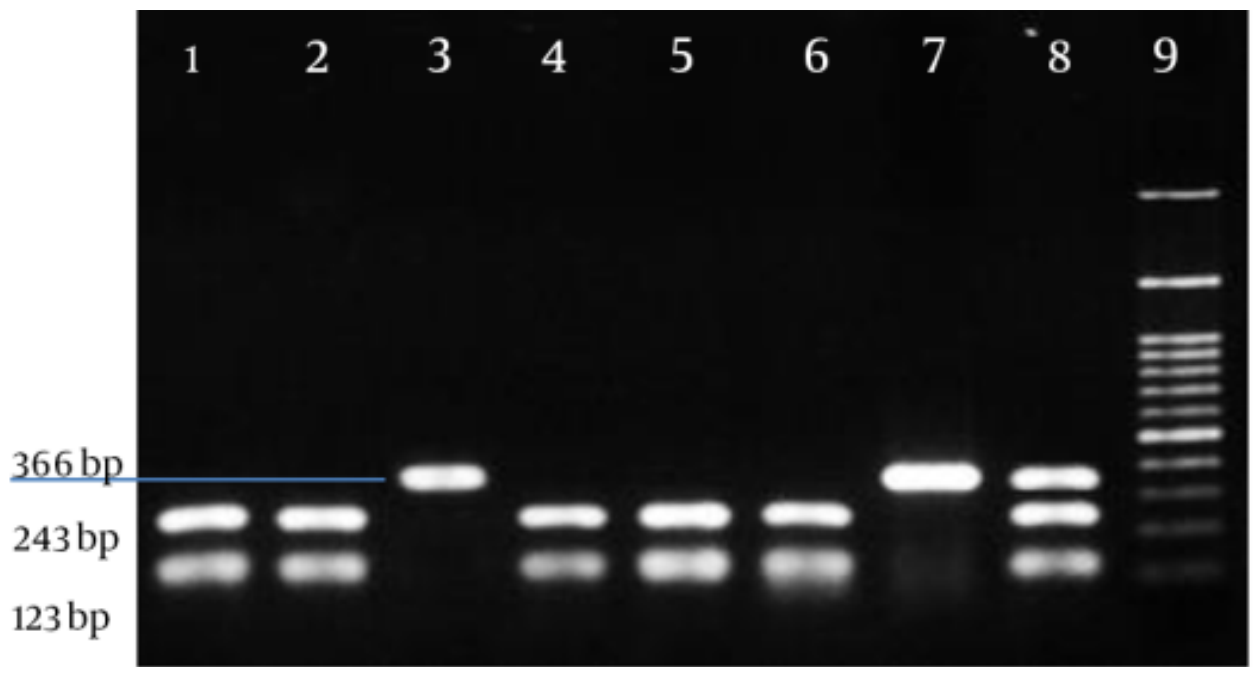

Fonte: FARD (2020).

Em relação aos genótipos do LEPR na pesquisa em questão, $A A, A G$ e $G G$ foram observados nas respectivas porcentagens: $47,8 \% ; 43,5 \%$ e $8,7 \%$. Assim, a maior porcentagem obtida foi do genótipo mutado, como demonstrado no gráfico 2. 
Segundo o estudo realizado por Oliveira e colaboradores (2013), polimorfismos no gene do LEPR - dentre eles a alteração LEPR Gln233Arg (c.668A>G) - estão intrinsecamente associados ao maior risco de desenvolvimento da obesidade $(p<0,05)$ e perfil lipídico aterogênico, corroborando com os dados obtidos no trabalho e sugerindo uma forte influência na resistência à leptina e um maior risco de alterações cardiovasculares. Ademais, o haplótipo estudado em 2013 foi relacionado ao IMC, a circunferência abdominal e a hiper leptinemias.

Gráfico 2: Análise dos genótipos do gene do LEPR apresentados pelos voluntários da pesquisa.

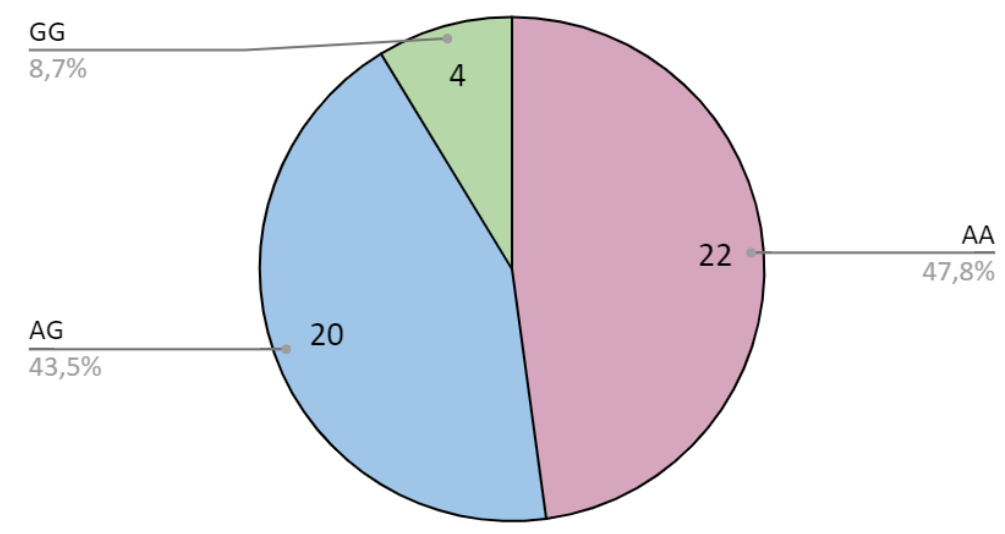

Fonte: Próprio autor.

A partir dos dados genéticos obtidos por meio da reação de PCR e das eletroforeses, aplicou-se o teste estatístico para se identificar se houve alguma diferença significativa nos resultados de participantes obesos. Tal diferença foi averiguada, na qual o valor $\mathrm{p}$ nesses pacientes se manteve abaixo de 0,05 $(p=0,04)$, demonstrando uma diferença estatística significativa. Já nos participantes normais e com sobrepeso, o valor $\mathrm{p}$ estava acima deste limiar de 0,05 ( $p=0,5592$ e $p=0,4235$, respectivamente).

Aplicou-se o teste de Shapiro-Wilk cujo parâmetro W corrobora com estes dados supracitados, pois quanto mais perto de 1 o parâmetro associado ao grupo está, indica uma distribuição normal dos dados obtidos, o que foi observado no quadro abaixo, no qual os pacientes obesos mantiveram os dados mais afastados de $1(W=0,7731)$, e os demais $(W=0,9340$ e $W=0,9077)$ mais próximos. 
Dessa forma, a pesquisa conseguiu estabelecer uma relação estatística entre indivíduos obesos e a presença dos polimorfismos -174G>C (rs1800795) no gene IL-6 e $668 \mathrm{~A}>\mathrm{G}$ (rs1137101) no gene LEPR.

Quadro 1: Resultados estatísticos dos pacientes organizados em grupos e de acordo com os valores $\mathrm{p}$ e de Shapiro-Wilk.

\begin{tabular}{|c|c|c|c|}
\hline RESULTADOS & NORMAL & OBESO & SOBREPESO \\
\hline Tamanho da amostra & 6 & 6 & 6 \\
\hline Média & 33,3167 & 33,3333 & 33,3333 \\
\hline Desvio padrão & 21,9731 & 28,1366 & 23,3809 \\
\hline W & 0,9340 & 0,7731 & 0,9077 \\
\hline$p$ & 0,5592 & 0,0400 & 0,4235 \\
\hline
\end{tabular}

Fonte: Próprio autor.

Partindo para a análise dos genótipos para os polimorfismos de IL-6 e de LEPR em associação, foi vista a seguinte distribuição: GG/AA $(21,7 \%)$; GC/AG $(15,2 \%)$; GC/AA $(23,9 \%)$; GG/AG (19,6\%); CC/AG (8,7\%) GC/GG (6,5\%); CC/AA; GG/GG (2,2\%). 0 gráfico 3 demonstra esses dados de forma ilustrativa e didática, na qual as colunas em azul indicam pacientes com apenas um genótipo mutado; as verdes sinalizam participantes dentro da normalidade para os dois genótipos; e a rosa denota os dois genótipos de interesse mutados.

Gráfico 3: Distribuição genotípica dos genes da IL-6 e do LEPR nos participantes analisados.

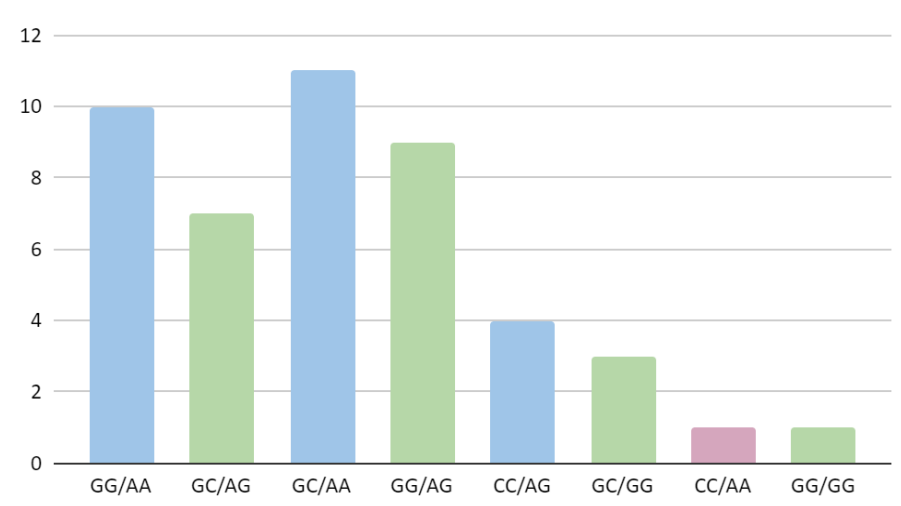

Indivíduos sem alteração genotípica

Indivíduos com 1 genótipo alterado

Indivíduos com 2 genótipos alterados

Fonte: Próprio autor. 
Assim, verificou-se que apenas um dos participantes teria a predisposição genética para a obesidade a partir dos dois polimorfismos analisados (-174G $>$ C de IL-6 e $668 \mathrm{~A}>\mathrm{G}$ de LEPR), entretanto o mesmo estava classificado como normal, através do IMC, até o momento da pesquisa. Para a complementação e compreensão dos dados apresentados, foram feitas interpretações ambientais por meio do questionário aplicado aos participantes.

Com os resultados obtidos no questionário, foi possível observar que fatores como sexo, idade e etnia não foram relevantes devido ao viés de seleção. Indivíduos do sexo feminino corresponderam a uma taxa de $86,7 \%$, enquanto os do sexo masculino englobaram apenas $13,3 \%$ dos voluntários. Em relação à faixa etária, foram apresentados os seguintes valores: $60-79$ anos (2,2\%), 40-49 anos (4,4\%), 30-39 anos (6,7\%), 25-29 anos (6,7\%), 20-24 anos (66,7\%) e 18-19 anos (13,3\%). Por fim, em relação à etnia, 2,2\% dos participantes se consideravam amarelos, $2,2 \%$ negros, $26,7 \%$ pardos e $68,9 \%$ brancos.

De acordo com a subdivisão de grupos realizada através do IMC, 52,2\% dos voluntários eram normais, $26,4 \%$ apresentavam sobrepeso e 4,3\% magreza, enquanto $17,4 \%$ foram classificados como obesos, como determinado no gráfico 4.

Gráfico 4: Separação dos grupos de indivíduos analisados na pesquisa de acordo com o Índice de Massa Corporal.

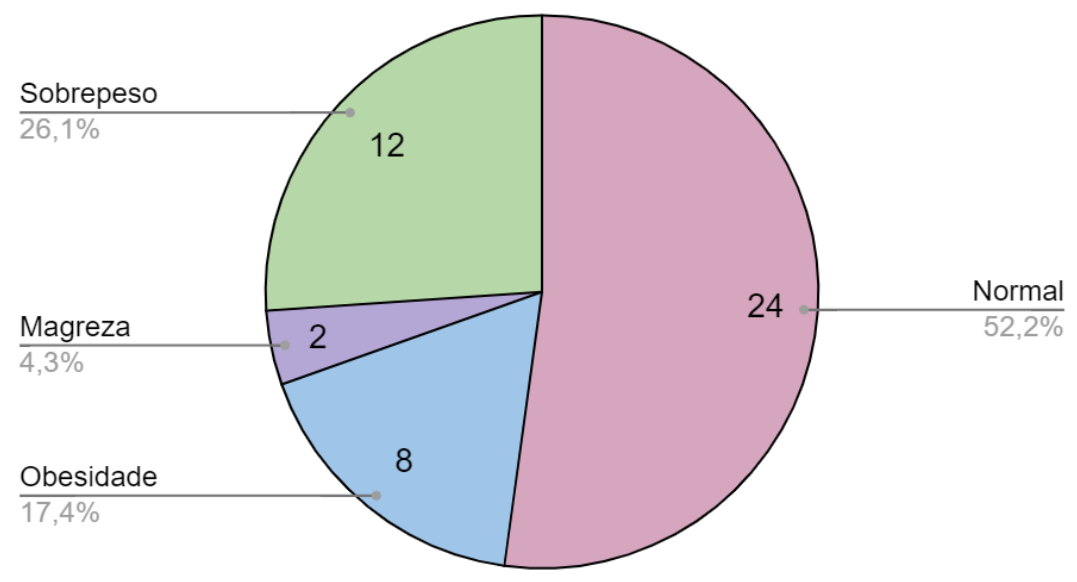

Fonte: Próprio autor.

Ao analisar os dados, de acordo com essa subdivisão apresentada, foi possível verificar que, no grupo de pessoas com valores de IMC dentro dos referenciais $(18,5$ a 24,9), 53,8\% apresentaram o genótipo GC, 38,5\% GG e 7,7\% CC para IL-6. Já em relação ao LEPR, 
$61,5 \%$ tinham o genótipo AA, 26,9\% AG e 11,5\% AG. Ao incluir os dados dos indivíduos com magreza nesse grupo, foram obtidas as seguintes taxas: $53,6 \%$ GC, 35,7\% GG e $10,7 \%$ CC (para IL-6); 60,7\% AA, 28,6\% AG e 10,7\% GG. Logo, não houve uma mudança expressiva dos resultados ao se ter a associação de indivíduos magros ao grupo.

Com essas porcentagens, foi verificado que existia uma quantidade significativa de pacientes considerados normais e magros com o genótipo mutado para LEPR $(60,7 \%)$. Fatores ambientais como prática de atividade física, alimentação adequada, ausência de parentes obesos e/ou com alguma doença podem justificar esta não alteração no IMC do paciente. Ao serem analisados os dados obtidos a partir do questionário, neste grupo anteriormente citado, 55,6\% das pessoas praticam atividade física e 44,4\% não realizam, contudo, $25 \%$ dos não praticantes de atividade não se consideram sedentários.

Nenhum dos voluntários relatou ser fumante e 8 pessoas consomem bebidas alcoólicas, sendo que 62,5\% utilizam de 1 a 2 vezes por mês e 37,5\% consomem de 1 a 3 vezes por semana. Partindo para a alimentação, $44,4 \%$ fazem de 4 a 5 refeições diárias e $55,6 \%$ se alimentam de 3 ou menos vezes por dia. Questionando-se sobre a troca de almoços por lanches, 66,7\% não realizam e 33,3\% fazem essa alteração.

Neste grupo, $72,2 \%$ marcaram que não consomem comidas muito doces, $61,1 \%$ que não utilizam muito sal na refeição e $83,3 \%$ disseram que não comem muita gordura, sendo que $75 \%$ retiram a gordura da carne e $62,5 \%$ removem a pele do frango. Nenhum deles é portador de alguma doença e 55,6\% não possuem parentes obesos.

Quadro 2: Síntese dos dados apresentados no questionário a respeito dos pacientes com IMC menor que $25 \mathrm{~kg} / \mathrm{m}^{2}$.

\begin{tabular}{|l|l|l|}
\hline \multicolumn{1}{|c|}{ INTERFERENTES } & SIM & NÃO \\
\hline Pratica atividade física? & $55,6 \%$ & $44,4 \%$ \\
\hline Troca almoços por lanches? & $33,3 \%$ & $66,7 \%$ \\
\hline Consome doces todo dia? & $27,8 \%$ & $72,2 \%$ \\
\hline Utiliza muito sal na refeição? & $38,9 \%$ & $61,1 \%$ \\
\hline Consome muita gordura? & $16,7 \%$ & $83,3 \%$ \\
\hline
\end{tabular}

Fonte: Próprio Autor. 
Dessa forma, foi possível estabelecer uma relação ambiental-genética sobre a expressão do polimorfismo, mas outros estudos com um $\mathrm{N}$ amostral maior devem ser feitos para, de fato, averiguar tal evidência. A presença do polimorfismo pode estar associada também a hereditariedade, de forma que $61,1 \%$ dos participantes possuem parentes com doenças predisponentes à obesidade, nas seguintes taxas: 90,9\% hipertensão; 63,6\% DM2; $45,5 \%$ outras doenças cardiovasculares; $9,1 \%$ hipercolesterolemia, porém outros genes devem estar associados ao aumento do IMC.

Já ao analisarmos os indivíduos normais e magros que possuem o genótipo mutante CC da IL-6, apenas 3 pessoas se encaixam nessa característica. Dentre elas, todas realizam atividades físicas, $66,7 \%$ delas consomem alimentos 3 vezes ou menos por dia e, na mesma porcentagem anterior, consomem bebida alcoólica. Nenhum dos participantes se interessa por comidas extremamente doces e nem apresentam doenças, entretanto todos possuem familiares com alguma doença de risco (DM2, HAS ou DCV), além de 33,3\% possuírem um parente obeso.

Finalizando a comparação dos voluntários normais e magros com determinados genótipos, o indivíduo CC/AA para os genes IL-6/LEPR, respectivamente, possui a predisposição genética para ambos os genes, sendo o único participante com tal característica. Todavia, ao observar o seu IMC, é considerado normal. Esta situação pode ser determinada devido a fatores ambientais marcados pelo participante, como praticar atividades físicas, não fumar, não beber, se alimentar de forma adequada durante os dias retirar a gordura dos alimentos - além de não possuir nenhuma doença e não utilizar medicamentos. Contudo, alguns fatores poderiam interferir neste caso, como consumir muito açúcar, preferir comidas salgadas e possuir familiar com hipertensão.

Partindo para o grupo de pessoas com sobrepeso, correspondentes a $26,1 \%$ dos voluntários da pesquisa, no gene da IL-6 as subsequentes taxas foram apresentadas: GG (50\%), GC (40\%) e CC (10\%). Analisando o gene do LEPR, as porcentagens alcançadas foram AA (40\%) e AG (60\%), não tendo nenhum paciente com o genótipo GG. Além da parte genética dos indivíduos que possuem os genótipos CC e/ou AA - da IL-6 e do LEPR respectivamente - fatores ambientais podem ser considerados interferentes significativos no IMC dos pacientes.

Observando-se apenas esta parcela mutada do grupo, $60 \%$ consomem gorduras e/ou óleos diariamente e, também na mesma porcentagem, possuem parentes obesos (mães, pais 
avós, tios e/ou primos) e familiares que têm doenças como DM2, HAS e DCV, o restante, que corresponde a $40 \%$ do grupo, não possui a informação sobre os familiares.

Em comparação ao grupo de indivíduos com sobrepeso que não possuem o genótipo alterado, fatores como o consumo de açúcar diários (representando uma taxa de $80 \%$ dos casos), ingestão de alimentos gordurosos (em $60 \%$ das vezes), utilização de medicamentos (80\% dos participantes), presença de parentes obesos na família ou com alguma doença relevante, podem ser sugestivos da alteração observada no IMC.

Com relação às pessoas obesas, que equivalem a $17,4 \%$ (8) do nosso $\mathrm{N}$ amostral, a análise genotípica correspondeu aos seguintes valores: GG (62,5\%), GC (25\%) e CC (12,5\%). Ao examinar o genótipo do LEPR nesses indivíduos, foi obtida a seguinte taxa: AA (12,5\%), AG $(75,0 \%)$ e GG $(12,5 \%)$. Logo, dessa forma apenas dois participantes apresentaram um genótipo mutado.

Assim, foi feita uma associação dos dados apresentados com os hábitos de vida de cada paciente, e percebeu-se que existe uma forte influência dos fatores ambientais, uma suspeita já levantada nos pacientes eutróficos e abaixo do peso - e corroborada pelo voluntário eutrófico com o genótipo mutado para ambos os genes.

Dentre os indivíduos obesos, hábitos como consumir gordura diariamente, comer comidas com bastante sal ou muitos doces foram relatados. Ademais, pôde-se observar que $50 \%$ dos indivíduos realizam atividades físicas e os outros $50 \%$ consideram-se sedentários. Ao serem questionados a respeito da quantidade de refeições diárias, 37,5\% dos indivíduos realizam 3 ou menos, enquanto 62,5\% fazem 4 a 5 refeições por dia.

Sobre o consumo de gorduras e/ou óleos, $75 \%$ dos obesos utilizam e os outros $25 \%$ não fazem o consumo diariamente. Dentre esse grupo, 2 deles apresentam doenças, que até então estão dissociadas da obesidade, e ao serem questionados sobre os parentes, apenas $25 \%$ relatou que não possui algum parente com determinada doença e o restante apresentou familiares com diversas alterações, dentre elas: HAS, DM2, DCV e Hipercolesterolemia. Além de que, em $50 \%$ dos casos, os voluntários apresentam familiares obesos, sendo citados: mãe, pai, irmãos e tios.

Apesar dos costumes alimentares e físicos dos participantes com obesidade, 4 em 8 disseram não ser obesos, o que revela uma preocupação sobre tais voluntários, já que têm uma percepção distorcida sobre si e seus hábitos, o que pode levar ao agravamento do quadro de obesidade, além de passarem a ter outras doenças associadas e predisponentes. 


\section{CONSIDERAÇÕES FINAIS}

De acordo com os resultados obtidos no presente estudo, estabeleceu-se que houve uma diferença significativa, dos polimorfismos $-174 \mathrm{G}>\mathrm{C}$ para IL-6 e $668 \mathrm{~A}>\mathrm{G}$ para LEPR, nos participantes obesos, corroborando com a literatura e cumprindo com os objetivos do trabalho.

Entretanto, também foi vista uma expressiva relação ambiental sobre a obesidade e o IMC dos participantes, já que no grupo de indivíduos eutróficos em conjunto com os participantes magros, foi vista uma grande porcentagem de genótipos mutados e mesmo assim estão abaixo do valor de sobrepeso. Isso foi fortemente observado no paciente com os dois genótipos mutados, que tem uma grande predisposição genética para o desenvolvimento da obesidade, mas por ter bons hábitos de vida, apresenta-se dentro dos parâmetros considerados normais de IMC.

Diante desta análise, é necessária uma concentração de pesquisas nesta área para haver a elucidação dos artifícios genéticos, tanto genotípicos quanto fenotípicos, que podem induzir ao avanço patológico.

Com essas verificações também é possível buscar formas de compreender as alterações genotípicas interligadas ao receptor de leptina e à interleucina-6 e, a partir disso, relacioná-las mais ainda à fatores ambientais como, por exemplo, a dieta e a prática de atividade física - e, de forma mais enfática, à epigenética.

Adiante espera-se encontrar formas diferenciadas para o tratamento desta doença, tais como o uso de anti-inflamatórios, se comprovado que é um quadro inflamatório, promovendo o retorno da homeostasia energética e havendo uma melhora na saúde física e psicológica dos participantes de uma maneira mais eficiente e, possivelmente, menos invasiva.

Por fim, a expectativa é de proporcionar recursos para intervenções dietoterápicas específicas e, com esse estudo, ajudar na implementação de campanhas para a melhoria do estilo de vida da sociedade, permitindo uma queda de casos de obesidade relacionados à causas externas que poderiam ser controlados ou até mesmo evitados com uma qualidade de vida adequada. 


\section{REFERÊNCIAS}

ABESO. Associação Brasileira para o Estudo da Obesidade e da Síndrome Metabólica. Diretrizes Brasileiras de Obesidade. 2016. 4 ed. São Paulo: São Paulo, 2016. Disponível em: https://portaldeboaspraticas.iff.fiocruz.br/wp-content/uploads/2018/05/57fccc403e5da.pdf. Acesso em: 12 jun. 2021.

AL OKAILY, F. et al. Genetic Polymorphisms in Transforming Growth Factor- $\beta$, Interferon- $\gamma$ and Interleukin-6 Genes and Susceptibility to Behcet's Disease in Saudi Population. Pharmacogenomics and Personalized Medicine, v. 13, p. 253-259, jul. 2020. DOI: 10.2147/PGPM.S249361.

ALI, Y. et al. Associação entre polimorfismo do gene da interleucina- 6 e regulação do ferro em pacientes em hemodiálise infectados pelo HCV. Brazilian Journal of Nephrology, v. 42, n. 4, p. 437-447, maio 2020. DOI: 10.1590/2175-8239- JBN-2019-0188.

CARVALHO, V. C. V. et al. Avaliação do Polimorfismo -174 G/C do gene IL-6 na Síndrome Coronariana Aguda no Nordeste do Brasil. 2016. 7 págs. Dissertação - Laboratório de Imunopatologia e Biologia Molecular, Departamento de Imunologia, Centro de Pesquisas Aggeu Magalhães (Fiocruz - PE); Real Hospital do Coração, Real Hospital Português (RHP); Laboratório de Biologia Parasitária, Centro de Pesquisas Gonçalo Moniz (Fiocruz - BA); Faculdade de Ciências Médicas (FCM), Universidade de Pernambuco (UPE); Laboratório de Virologia e Terapia Experimental, Departamento de Virologia, Centro de Pesquisas Aggeu Magalhães (Fiocruz - PE); Pernambuco, 2016. DOI: 10.5935/2359-4802.20160048.

FARD, Z. T. Evaluation of Leptin Receptor Q223R (rs1137101) Polymorphism Based on Histopathological and Body Mass Index Characteristics in Iranian Females with Breast Cancer. International Journal of Cancer Management, v. 13, n. 4, abr. 2020. DOI: 10.5812/ijcm.92731.

FUNGHETTO, S. S. Associação do polimorfismo -174 G/C da região promotora do gene IL-6 com a produção de marcadores inflamatórios após o exercício de força excêntrico em idosas obesas. 2014. 83f. Dissertação para Doutorado - Programa de Pós Graduação em Ciências da Saúde, Universidade de Brasília, Distrito Federal, 2014.

GENECARDS. IL-6 Gene. 2021a. Disponível em: https://www.genecards.org/cgi-bin/carddisp.pl?gene=IL6\&keywords=il,6. Acesso em: 12 ago. 2021.

GENECARDS. LEP Gene. 2021b. Disponível em: https://www.genecards.org/cgi-bin/carddisp.pl?gene=LEP. Acesso em: 12 ago. 2021.

GENECARDS. LEPR Gene. 2021c. Disponível em: https://www.genecards.org/cgi-bin/carddisp.pl?gene=LEPR\&keywords=lepr. Acesso em: 12 ago. 2021.

GHOSH, S.; ASHCRAFT, K. An IL-6 link between obesity and cancer. 2013. 18 págs. Department of Molecular Medicine, Institute of Biotechnology, University of Texas Health 
Science Centre at San Antonio, Texas, United States of America, 2013. Disponível em: https://www.fbscience.com/Elite/articles/pdf/Elite628.pdf. Acesso em: 12 jul. 2021.

GOYENECHEA, E.; PARRA, M. D.; HERNÁNDEZ, J. A. M. Implicación de la IL-6 y su polimorfismo -174G>C en el control del peso corporal y en las complicaciones metabólicas asociadas a la obesidad. 2005. 10 págs. Artigo de Revião - Departamento de Fisiología y Nutrición, Universidad de Navarra, Pamplona, España, 2005. Disponível em: https://scielo.isciii.es/pdf/asisna/v28n3/revision1.pdf. Acesso em: 12 jul. 2021.

MATSUOKA, N. et al. Human leptin receptor gene in obese Japanese subjects: evidence against either obesity-causing mutations or association of sequence variants with obesity. Diabetologia, v. 40, n. 10, p. 1204-1210, 1997. DOI: 10.1007/s001250050808.

NUSSBAUM, R. L. et al. Diversidade Genética Humana: Mutação e Polimorfismo. Thompson \& Thompson Genética Médica. 7 ed. Rio de Janeiro: Elsevier, 2008. Disponível em: https://edisciplinas.usp.br/pluginfile.php/5717717/mod_resource/content/3/cap.4\%20Thom pson.pdf. Acesso em: 18 jun. 2021.

OLIVEIRA, R. Estudo de variantes da leptina e do receptor da leptina: impacto sobre as características relacionadas à obesidade. 2008. 113 págs. Dissertação para Mestrado Faculdade de Ciências Farmacêuticas, Universidade de São Paulo, São Paulo, 2008. Disponível em: https://pdfs.semanticscholar.org/f5e4/761b55cf6333de1b16f98711dc00bc39b697.pdf. Acesso em: 18 jul. 2021.

OLIVEIRA, R. Interação entre polimorfismos de genes envolvidos na homeostase energética e na sensibilidade à insulina e a resposta à uma intervenção dietética para redução do peso corporal em indivíduos obesos. 2011. 153 págs. Dissertação para Doutorado - Faculdade de Ciências Farmacêuticas, Universidade de São Paulo, São Paulo, 2011. Disponível em: https://teses.usp.br/teses/disponiveis/9/9136/tde-26042013-101631/publico/Doutorado_R aquel_de_Oliveira.pdf. Acesso em: 12 jul. 2021.

OLIVEIRA, R. et al. Leptin receptor gene polymorphisms are associated with adiposity and metabolic alterations in Brazilian individuals. Arquivos Brasileiros de Endocrinologia e Metabologia, v. 57, n. 9, p. 677 - 684, 2013. DOI: 10.1590/S0004-27302013000900002.

PIRES, K. C. et al. Polimorfismo do Receptor da Interleucina-6 e sua associação com níveis de Proteína C Reativa em indivíduos com Síndrome Metabólica. 2009. 3 págs. Iniciação científica - Faculdade de Farmácia, Enfermagem, Nutrição e Fisioterapia, Pontifícia Universidade Católica do Rio Grande do Sul (PUCRS), Rio Grande do Sul, 2009.

ROCHA, A. P. et al. Polimorfismos genéticos: implicações na patogênese do carcinoma medular de tireóide. Arquivos Brasileiros de Endocrinologia \& Metabologia, v. 51, n. 5, p. 723-730, jan. $2007 . \quad$ Disponível em: https://www.scielo.br/j/abem/a/HbHgZkYPkc7SP6HDQcv9tcr/?lang=pt\&format=pdf. Acesso em: 18 jul. 2021.

SOBHAN, M. R. et al. Associação do polimorfismo IL-6-174G> C (rs1800795) com escoliose idiopática da adolescência: Evidências de um estudo de caso-controle e metanálise. Revista Brasileira de Ortopedia, Rio de Janeiro, v. 55, p. 17-26, 2020. DOI: 10.1055/s-0039-1700813. 
STEEMBURGO, T.; AZEVEDO, M. J.; MARTÍNEZ, J. A. Interação entre gene e nutriente e sua associação à obesidade e ao diabetes melito. 2009. 12 págs. Artigo de Revisão - Serviço de Endocrinologia, Hospital de Clínicas de Porto Alegre, Universidade Federal do Rio Grande do Sul (UFRGS), Rio Grande do Sul; Departamento de Fisiología y Nutrición, Universidad de Navarra, Pamplona, España, 2009. DOI: 10.1590/S0004-27302009000500003.

TONET, A. C.; NÓBREGA, O. T. Imunossenescência: a relação entre leucócitos, citocinas e doenças crônicas. 2008. 16 págs. Artigo de Revisão - Programa de Pós-Graduação Stricto Sensu em Gerontologia, Universidade Católica de Brasília, Distrito Federal, 2008. DOI: 10.1590/1809-9823.2008.110210.

VARGAS, V. R. A. Influência do polimorfismo 48867A>C (Asp358Ala) do gene do receptor da interleucina 6 na resposta a uma intervenção para modificação do estilo de vida em indivíduos com síndrome metabólica. 2012. 50 págs. Dissertação para Pós-Graduação Faculdade de Biociências, Pontifícia Universidade Católica do Rio Grande do Sul (PUCRS), Rio Grande do Sul, 2012. Disponível em: http://tede2.pucrs.br/tede2/handle/tede/5449. Acesso em: 15 jul. 2021.

WANDERLEY, E. N.; FERREIRA, V. A. Obesidade: uma perspectiva plural. 2007. 10 págs. Artigo de Revisão - Departamento de Nutrição, Universidade Federal dos Vales do Jequitinhonha e Mucuri (UFVJM), Minas Gerais, 2007. Disponível em: https://www.scielosp.org/article/ssm/content/raw/?resource_ssm_path=/media/assets/csc/ v15n1/a24v15n1.pdf. Acesso em: 18 jul. 2021. 


\section{APÊNDICES}

APÊNDICE A - Questionário para coleta de dados dos voluntários da pesquisa.

\section{QUESTIONÁRIO PARA A COLETA DE DADOS DO PARTICIPANTE DA PESQUISA}

Este formulário tem como objetivo a obtenção de dados dos voluntários da pesquisa "Associação entre a obesidade e os polimorfismos da Interleucina-6 e do Receptor de Leptina", para podermos avaliar o seu estilo de vida e a sua associação com a obesidade.

E-mail do participante:

Termo de Consentimento Livre e Esclarecido - TCLE

"Associação entre a obesidade e os polimorfismos da Interleucina-6 e do Receptor de Leptina"

Instituição dos pesquisadores: Centro Universitário de Brasília - UniCEUB

Pesquisador responsável: Paulo Roberto Martins Queiroz

Pesquisadoras assistentes: Giovanna Sousa de Castro Ribeiro e Isabella de Freitas Cavalcante

Você está sendo convidado(a) a participar voluntariamente do projeto de pesquisa acima citado. O texto abaixo contém todas as informações necessárias sobre a pesquisa que estamos fazendo. Sua colaboração neste estudo será de muita importância para nós, mas se desistir a qualquer momento, isso não causará nenhum prejuízo.

O nome deste documento que você está lendo é Termo de Consentimento Livre e Esclarecido (TCLE). Antes de decidir se autoriza a sua participação (de livre e espontânea vontade) você deverá ler e compreender todo o conteúdo. Ao final, caso decida autorizar, você será solicitado a assiná-lo e receberá uma cópia do mesmo. Antes de assinar faça 
perguntas sobre tudo o que não tiver entendido bem. A equipe deste estudo responderá às suas perguntas a qualquer momento (antes, durante e após o estudo).

Natureza e objetivos do estudo:

- O objetivo específico deste estudo é avaliar os polimorfismos genéticos associados à obesidade em adultos e idosos.

- Você está sendo convidado a participar, pois faz parte da comunidade do UniCEUB. O critério de exclusão se dá por pessoas que estão fazendo dieta com prescrição medicamentosa.

Procedimentos do estudo:

- Sua participação consiste na doação de uma amostra do seu DNA.

- O procedimento de extração do DNA ocorre através do enxágue bucal, ou eventualmente, por meio da coleta sanguínea, caso seja necessário. Também deverá ser feito o preenchimento do "Questionário de Coleta de Dados do Paciente" para avaliação do seu estilo de vida e suas associações com a obesidade.

- Não haverá nenhuma outra forma de envolvimento ou comprometimento neste estudo.

- A pesquisa será realizada nos laboratórios (Labocien) do Centro Universitário de Brasília (UniCEUB).

Riscos e benefícios:

- Este estudo possui baixos riscos ao participante da pesquisa. O voluntário poderá ter uma leve ânsia devido ao enxágue de uma solução de água e açúcar e caso isso ocorra, o participante fará o bochecho só com água comum e deverá ingerir água para reverter o incômodo. Outro risco seria o sangramento caso seja necessária a realização da coleta sanguínea e, para este ser resolvido, será feita a limpeza e a adição de um curativo para estancar o sangramento.

- Medidas preventivas, como blood-stop, serão tomadas durante a coleta sanguínea pelos pesquisadores capacitados para minimizar qualquer risco ou incômodo.

- Caso esse procedimento possa gerar algum tipo de constrangimento, você não precisa realizá-lo. 
- Com sua participação nesta pesquisa você poderá fornecer/terá dados sobre os polimorfismos da interleucina-6 e do receptor de leptina e a sua interação com a obesidade, além de contribuir para maior conhecimento sobre o levantamento dos genes e hábitos de vida da comunidade do UniCEUB.

Participação, recusa e direito de se retirar do estudo:

- Sua participação é voluntária. Você não terá nenhum prejuízo se não quiser participar.

- Você poderá se retirar desta pesquisa a qualquer momento, bastando para isso entrar em contato com um dos pesquisadores responsáveis.

- Conforme previsto pelas normas brasileiras de pesquisa com a participação de seres humanos, você não receberá nenhum tipo de compensação financeira pela sua participação neste estudo.

Confidencialidade:

- Seus dados serão manuseados somente pelos pesquisadores e não será permitido o acesso a outras pessoas.

- Os dados e instrumentos utilizados, a amostra do DNA e os questionários, ficarão guardados sob a responsabilidade de Paulo Roberto Martins Queiroz com a garantia de manutenção do sigilo e confidencialidade, e arquivados por um período de 5 anos; após esse tempo serão destruídos.

- Os resultados deste trabalho poderão ser apresentados em encontros ou revistas científicas. Entretanto, ele mostrará apenas os resultados obtidos como um todo, sem revelar seu nome, instituição a qual pertence ou qualquer informação que esteja relacionada com sua privacidade.

Se houver alguma consideração ou dúvida referente aos aspectos éticos da pesquisa, entre em contato com o Comitê de Ética em Pesquisa do Centro Universitário de Brasília CEP/UniCEUB, que aprovou esta pesquisa, pelo telefone (61) 3966-1511 ou pelo e-mail cep.uniceub@uniceub.br Também entre em contato para informar ocorrências irregulares ou danosas durante a sua participação no estudo. 
Precisamos do seu consentimento para prosseguirmos.

( ) Após receber a explicação completa dos objetivos do estudo e dos procedimentos envolvidos nesta pesquisa, eu concordo voluntariamente em fazer parte deste estudo.

Pesquisadores responsáveis (selecione todos)

( ) Paulo Roberto Martins Queiroz - celular (61) 981624732

- e-mail paulo.silva@ceub.edu.br

( ) Giovanna Sousa de Castro Ribeiro - celular (61) 992044420

- e-mail giovanna.sousa@sempreceub.com

( ) Isabella de Freitas Cavalcante - celular (61) 991187454

- e-mail isabella.fc@sempreceub.com

Nome do participante:

Número de celular para contato (adicionar DDD): 


\section{QUESTIONÁRIO}

Faixa etária:

( ) $18-19$ anos

( ) 20 - 24 anos

( ) 25 - 29 anos

( ) $30-39$ anos

( ) 40 - 49 anos

( ) 50 - 59 anos

( ) 60 - 79 anos

( ) 80 anos ou mais

Sexo: ( ) Feminino ( ) Masculino

Caso a opção anterior seja "Feminino", já está em menopausa? ( ) Sim （ ) Não

Etnia: ( ) Branca ( ) Parda ( ) Negra ( ) Amarela

Profissão:

Na sua profissão há exigência de esforço físico? ( ) Sim ( ) Não

Realiza alguma atividade física? ( ) Sim ( ) Não

Caso a resposta anterior seja "Não", você se considera sedentário? ( ) Sim ( ) Não

É fumante? ( ) Sim ( ) Não

Caso a resposta anterior seja "Sim", qual é a quantidade de cigarros por dia?

Consome bebida alcóolica com qual frequência:

( ) Nunca

( ) 1-2 vezes por mês

( ) 1-3 vezes por semana

( ) 4 ou mais vezes por semana 
Quantas refeições você faz por dia? ( ) 3 ou menos ( ) 4 a 5 ( ) 6 ou mais

Costuma trocar almoços por lanches? ( ) Sim ( ) Não

Consome açúcar e/ou doces diariamente? ( ) Sim ( ) Não

Consome gorduras e/ou óleos diariamente? ( ) Sim ( ) Não

Ao comer carne vermelha você tira a gordura? ( ) Sim ( ) Não

Ao comer frango você tira a pele? ( ) Sim ( ) Não

Gosta de comidas muito doces? ( ) Sim ( ) Não

Gosta de comida com muito sal? ( ) Sim ( ) Não

Gosta de comida com muita gordura? ( ) Sim ( ) Não

É obeso? ( ) Sim ( ) Não

Altura:

Peso:

É portador de alguma doença? ( ) Sim ( ) Não

Caso a resposta anterior seja "Sim", quais são? (Pode ser marcada mais de uma opção)

( ) Diabetes Mellitus tipo 2

( ) Hipertensão (Doença Cardiovascular)

( ) Outras Doenças Cardiovasculares

( ) Hipercolesterolemia

( ) Outros...

Já teve infarto? ( ) Sim ( ) Não

Faz uso de medicamento? ( ) Sim ( ) Não

Caso a resposta anterior seja "Sim", quais são e há quanto tempo está utilizando?

Possui parentes obesos? Se sim, quais? (Pode ser marcada mais de uma opção)

( ) Mãe/pai

( ) Irmãos

( ) Avós

( ) Tios 

( ) Primos
( ) Outros...

Possui algum parente com: (Pode ser marcada mais de uma opção)

( ) Diabetes Mellitus tipo 2

( ) Hipertensão

( ) Hipercolesterolemia

( ) Doenças cardiovasculares

( ) Não tem

( ) Não sabe 